\title{
Type 1 Diabetes Associated with Asymptomatic Acromegaly Successfully Treated with Surgery after Pregnancy: A Case Report
}

\author{
HIROSHI IWAI, HIROYUKI ITO, SARI RI, TAKESHI HARADA, NORIYUKI HIROTA, TAKAAKI YAMAUCHI, \\ TOSHIYUKI MIYATAKE, YASUHIRO OHNO AND NORIHIKO AOKI
}

Department of Endocrinology, Metabolism and Diabetes, Kinki University School of Medicine, Osaka 589-8511, Japan

\begin{abstract}
We report a rare case of type 1 diabetes in a woman associated with acromegaly who was treated with surgery after pregnancy. An 18-year-old woman came to our hospital in April, 1998, complaining of thirst, polydipsia, polyuria, appetite loss, body weight loss of $8 \mathrm{~kg}$ in a month, and amenorrhea beginning 2 months earlier. Based on laboratory data, she was diagnosed as having type 1 diabetes mellitus. Although we suspected her of having acromegaly because of high growth hormone $(\mathrm{GH})$ levels $(6.9$ or $8.5 \mathrm{ng} / \mathrm{ml})$, blood levels of insulin-like growth factor 1 (IGF-1) and IGF-binding protein-3 (IGFBP-3) were within normal range and the circadian rhythm of her blood GH levels was normally maintained. Her blood GH level was elevated to $12.6 \mathrm{ng} / \mathrm{ml} 15$ minutes after a TRH administration. Blood GH levels were suppressed from $49 \mathrm{ng} / \mathrm{ml}$ to $1.5 \mathrm{ng} / \mathrm{ml} 4$ hours after an oral administration of $2.5 \mathrm{mg}$ of bromocriptine. A magnetic resonance images (MRIs) showed pituitary swelling, but no nodules were found in the pituitary. Therefore, we diagnosed her as having acromegaly and observed her without surgery, while prescribing diet therapy and intensive insulin therapy for diabetes. We started a treatment of oral administration of $7.5 \mathrm{mg}$ of bromocriptine per day for the acromegaly from April 28, 2000, because her elevated GH was suspected of causing her diabetes to be poorly controlled. During a pregnancy from October, 2000 to September, 2001, diabetic control was improved with increased administration of insulin under a constant dose of bromocriptine. She delivered a normal full-term infant. After the bromocriptine therapy was stopped as she hoped to breastfeed, blood levels of GH and IGF-1 became elevated and her diabetic control deteriorated. As her pituitary tumor observed in pituitary MRIs became larger during the course, a transsphenoidal surgery was performed on March 8, 2002. After the surgery, blood levels of GH and IGF-1 lowered and diabetic control improved again. We concluded as follows: to rule out acromegaly in patients with poorly controlled diabetes, 1) measurements of serum GH and IGF-1 should be performed, and 2) pituitary MRIs should be performed if blood levels of GH or IGF-1 are high.
\end{abstract}

Key words: Type 1 diabetes mellitus, Acromegaly, Pregnancy, Bromocriptine

(Endocrine Journal 52: 413-420, 2005)

\begin{abstract}
ACROMEGALY is a disease induced by a growth hormone $(\mathrm{GH})$-producing tumor. The excessive production of GH and insulin-like growth factor 1 (IGF-1) causes various diseases such as diabetes mellitus, hypertension, and hyperlipidemia, of which the frequency of diabetes is $5-32 \%[1,2]$. Diabetes in acromegaly is

Received: March 12, 2004

Accepted: April 4, 2005

Correspondence to: Dr. Hiroshi IWAI, Department of Endocrinology, Metabolism and Diabetes, Kinki University School of Medicine, 377-2, Ohno-Higashi, Osaka-Sayama, Osaka 589-8511, Japan
\end{abstract}

due to a mechanism in which excessive GH production induces both hyperinsulinemia and insulin resistance, leading to elevated blood glucose levels [2-4]. In type 1 diabetes, particularly if it is poorly controlled, blood $\mathrm{GH}$ levels are generally higher and fluctuate more than in non-diabetics because their deficient endogeneous insulin tends to increase GH secretion [4-6].

The diagnostic evaluation of acromegaly is usually undertaken by noting typical clinical symptoms, high blood levels of GH and IGF-1, and the existence of a pituitary tumor seen in magnetic resonance images (MRIs) [1]. The measurement of serum IGF-1 and IGF-binding protein-3 (IGFBP-3) has been reported as 
being valuable for the diagnosis of acromegaly in type 1 diabetes [7, 8]. However, it may be sometimes difficult to diagnose acromegaly associated with type 1 diabetes because insulin, GH and IGF-1 may mutually interfere with each other on secretion [9].

We report a rare case of type 1 diabetes with acromegaly, which was diagnosed by endocrinological stimulation tests and pituitary MRIs and successfully treated with surgery after pregnancy.

\section{Clinical Course}

An 18-year-old woman came to our hospital on April 9, 1998, complaining of thirst, polydipsia, polyuria, appetite loss, body weight loss of $8 \mathrm{~kg}$ in a month, and amenorrhea beginning 2 months earlier, but not of headache. Based on laboratory data showing a high blood glucose level $(547 \mathrm{mg} / \mathrm{dl})$ and positive urinary acetone body (Table 1), she was diagnosed as suffering from diabetic ketosis. As her blood GH level was $3.5 \mathrm{ng} / \mathrm{ml}$, which was above the normal range of below $3.0 \mathrm{ng} / \mathrm{ml}$ (enzyme immunoassay, EIA), acromegaly was also suspected. She was admitted to our hospital in April, 1998, to undergo examinations and treatment for diabetes associated with elevated blood GH.

Her physical examinations on admission were as follows: height $162.1 \mathrm{~cm}$, body weight $50.6 \mathrm{~kg}$, body mass index (BMI) 19.3, blood pressure 118/76 mmHg. Thyroid was not palpable and no nodule was palpated in her thyroid. She had neither visual disturbances nor diplopia. She had no abnormalities in the heart, lungs or abdomen. She had no typical symptoms of acromegaly, such as enlarged hands and feet, exaggerated nasolabial folds, thick lips, giant tongue, etc. Tendon reflex was normal. Heel pad of $16 \mathrm{~mm}$ was within normal range. Radiograph of the finger showed normal. Her fingers were not thickened and did not have spadelike distal tufts.

We diagnosed her as having type 1 diabetes mellitus based on data showing low levels of urinary C-peptide (CPR) excretion (10.4 $\mu \mathrm{g}$ /day) (Table 1) and a high titer of anti-glutamic acid decarboxylase (GAD) antibodies $(29.1 \mathrm{U} / \mathrm{ml})$ (Table 2). There was hyperglycemia, but there were no abnormal findings in blood cell count, renal function, liver function, or blood amylase levels (Table 1). She did not have diabetic neuropathy, retinopathy or nephropathy. Although blood levels of CEA $(6.1 \mathrm{ng} / \mathrm{ml})$ and CA19-9 $(110 \mathrm{U} / \mathrm{ml})$ were ele-
Table 1. Laboratory data on admission in March, 1998

\begin{tabular}{|c|c|}
\hline \multicolumn{2}{|l|}{ Blood cell count } \\
\hline WBC & $6300 / \mu 1$ \\
\hline $\mathrm{RBC}$ & $580 \times 10^{4} / \mu 1$ \\
\hline $\mathrm{Hb}$ & $12.1 \mathrm{~g} / \mathrm{dl}$ \\
\hline $\mathrm{Ht}$ & $40.7 \%$ \\
\hline Plt & $49.5 \times 10^{4} / \mu 1$ \\
\hline $\mathrm{Na}$ & $138 \mathrm{mEq} / \mathrm{l}$ \\
\hline $\mathrm{K}$ & $4.3 \mathrm{mEq} / 1$ \\
\hline $\mathrm{Cl}$ & $95 \mathrm{mEq} / 1$ \\
\hline $\mathrm{Ca}$ & $9.0 \mathrm{mg} / \mathrm{dl}$ \\
\hline $\mathrm{Pi}$ & $3.5 \mathrm{mg} / \mathrm{dl}$ \\
\hline BUN & $12 \mathrm{mg} / \mathrm{dl}$ \\
\hline $\mathrm{Cr}$ & $0.5 \mathrm{mg} / \mathrm{dl}$ \\
\hline $\mathrm{TP}$ & $8.6 \mathrm{~g} / \mathrm{dl}$ \\
\hline Albumin & $4.7 \mathrm{~g} / \mathrm{dl}$ \\
\hline Blood glucose & $547 \mathrm{mg} / \mathrm{dl}$ \\
\hline T. Bil & $0.8 \mathrm{mg} / \mathrm{dl}$ \\
\hline GOT & $20 \mathrm{IU} / 1$ \\
\hline GPT & $26 \mathrm{IU} / 1$ \\
\hline Alp & 309 IU/1 \\
\hline Amy & $76 \mathrm{IU} / \mathrm{ml}$ \\
\hline $\mathrm{TC}$ & $271 \mathrm{mg} / \mathrm{dl}$ \\
\hline Trig & $283 \mathrm{mg} / \mathrm{dl}$ \\
\hline \multicolumn{2}{|l|}{ Tumor markers } \\
\hline CEA & $6.1 \mathrm{ng} / \mathrm{ml}(<5)^{*}$ \\
\hline CA19-9 & $110 \mathrm{U} / \mathrm{ml}(<37)$ \\
\hline \multicolumn{2}{|l|}{ Urinalyses } \\
\hline Glucose & $(4+)$ \\
\hline Protein & $(-)$ \\
\hline Blood & $(-)$ \\
\hline Acetone body & $(3+)$ \\
\hline \multicolumn{2}{|c|}{$24 \mathrm{hr}$ urinary excretion } \\
\hline Total volume & $1000 \mathrm{ml}$ \\
\hline $\mathrm{Cr}$ & $0.6 \mathrm{~g} /$ day \\
\hline C-peptide & $10.4 \mu \mathrm{g} / \mathrm{day}$ \\
\hline Glucose & $0 \mathrm{~g} /$ day \\
\hline Protein & $0.1 \mathrm{~g} / \mathrm{day}$ \\
\hline Albumin & $8.3 \mathrm{mg} / \mathrm{day}$ \\
\hline Ccr & $125.9 \mathrm{ml} / \mathrm{min}$ \\
\hline
\end{tabular}

Abbreviations: CEA, carcinoembryonic antigen; CA19-9, carbohydrate antigen; Ccr, creatinine clearance.

* Numbers in parentheses indicate the normal range.

vated (Table 1), no malignancies were seen on images such as abdominal computed tomography (CT) scan, gastro-intestinal fiberscopy, or barium enema.

Although her blood GH levels ( 6.9 or $8.5 \mathrm{ng} / \mathrm{ml})$ and urinary $\mathrm{GH} / \mathrm{Cr}$ excretion $(24.1 \mathrm{pg} / \mathrm{mgCr})$ were both high, blood levels of IGF-1 (316 ng/ml, immunoradiometric assay, IRMA) and IGFBP-3 $(2.64 \mu \mathrm{g} / \mathrm{ml}$, radioimmunoassay, RIA) were within the normal range (Tables 2, 3). The responses of GH, PRL, and TSH to TRH were discrepancy hyperactive (as blood GH level 
increased to $12.6 \mathrm{ng} / \mathrm{ml})$, hyperactive, and hypoactive, respectively (Fig. 1A). Blood levels of GH at 4 hours and PRL at 6-8 hours after an oral administration of $2.5 \mathrm{mg}$ of bromocriptine were suppressed from $4.9 \mathrm{ng} /$ $\mathrm{ml}$ to $1.5 \mathrm{ng} / \mathrm{ml}$ and from $20.2 \mathrm{ng} / \mathrm{ml}$ to $<1.0 \mathrm{ng} / \mathrm{ml}$, respectively (Fig. 1B). Although her fasting blood GH level in the morning was slightly high, the circadian rhythm of her blood GH levels was normally maintained (Fig. 1C). The responses of GH, LH and FSH in an LH-RH stimulation test were normal (data not shown). Just after the LH-RH stimulation test, menstruation restarted and her menstrual rhythm improved

Table 2. Endocrinological laboratory data in March, 1998

\begin{tabular}{ll}
\hline GH & $8.5 \mathrm{ng} / \mathrm{ml}$ \\
PRL & $3.8 \mathrm{ng} / \mathrm{ml}$ \\
Cortisol & $12.1 \mu \mathrm{g} / \mathrm{dl}$ \\
ACTH & $19 \mathrm{pg} / \mathrm{dl}$ \\
TSH & $1.5 \mu \mathrm{IU} / \mathrm{ml}(0.5-4.8)^{*}$ \\
Free-T4 & $1.0 \mathrm{ng} / \mathrm{dl}(0.8-1.5)$ \\
LH & $2.7 \mathrm{mIU} / \mathrm{ml}(8.7-38.0)$ \\
FSH & $4.6 \mathrm{mIU} / \mathrm{ml}(26.2-113.3)$ \\
Epinephrine & $17 \mathrm{pg} / \mathrm{ml}(<100)$ \\
Norepinephrine & $31 \mathrm{pg} / \mathrm{ml}(100-450)$ \\
Dopamine & $5>\mathrm{pg} / \mathrm{ml}(<20)$ \\
Glucagon & $106 \mathrm{pg} / \mathrm{ml}(23-197)$ \\
Gastrin & $15>\mathrm{pg} / \mathrm{ml}$ \\
Intact-PTH & $19 \mathrm{pg} / \mathrm{ml}(14-86)$ \\
1 $\alpha-25(O H) 2 V D$ & $23.9 \mathrm{pg} / \mathrm{dl}(27.5-68.7)$ \\
Calcitonin & $28 \mathrm{pg} / \mathrm{dl}(15-86)$ \\
Auto-antibodies & \\
GAD antibody & $29.1 \mathrm{U} / \mathrm{ml}(<1.5)$ \\
Insulin antibody & $6.1 \%(<7)$ \\
ANA & $(1+\mathrm{w})$ \\
Anti-pituitary antibody & $(-)$ \\
TGPA & $10>$ \\
MCPA & $10>$ \\
\end{tabular}

Abbreviations: GAD, glutamic acid decarboxylase; ANA, antinuclear antibody; TGPA, anti-thyroglobulin particle agglutination; MCPA, anti-thyroid microsomal particle agglutination.

* Numbers in parentheses indicate the normal range. since February, 2002. An enhanced MRI on May 1, 1998, showed pituitary swelling, but no nodule in the pituitary (Fig. 2A, B). Thus, based on endocrinological data, we diagnosed her as having acromegaly.

Blood levels of cortisol, ACTH, free T4, TSH, PRL, $\mathrm{LH}$, and FSH were normal. Both the anti-GAD antibodies and anti-nuclear bodies were positive, and, conversely, the antibodies against insulin, the pituitary and the thyroid were all negative (Table 2). Blood levels of calcium, phosphorus, intact-PTH, $1 \alpha-25(\mathrm{OH})_{2} \mathrm{VD}$, cathecholamine, glucagon, gastrin, and calcitonin were all normal (Table 1,2$)$. She did not have any tumors on neck- and abdomen ultrasonography or abdominal CT scans. Thus, we excluded multiple endocrine neoplasia type 1 (MEN1) and diagnosed her condition as plain acromegaly. We prescribed diet therapy $(1400 \mathrm{Kcal} /$ day) and an intensive insulin therapy of rapid-acting insulin (Penfill $\mathrm{R}^{\mathrm{R}}$ ) at each meal and intermediate-acting $\mathrm{NPH}$ insulin (Penfill $\mathrm{N}^{\mathrm{R}}$ ) at bedtime for her diabetes.

Diabetic control just after leaving the hospital on June 12, 1998 was good (HbA1c 6.1\%). Subsequently, we increased the insulin dose from 22 units to 40 units per day because her blood glucose levels fluctuated between hypo- and hyperglycemia. We started the treatment of oral administration of $7.5 \mathrm{mg}$ of bromocriptine per day for the acromegaly beginning April 28, 2000, because high blood levels of GH were suspected of causing her diabetes to be poorly controlled. However, she rejected octoreotide therapy because octoreotide was expensive. During her pregnancy from October, 2000 to September, 2001, diabetic control improved by the oral administration of bromocriptine and increased insulin injection (Fig. 3). While she was receiving the treatments of the oral administration of bromocriptine for acromegaly and the insulin injections for type 1 diabetes, she became pregnant and delivered a normal male infant at 41 weeks (weight: $3936 \mathrm{~g}$ ). The baby transiently had hypoglycemia (blood glucose levels

Table 3. Changes with time in blood levels of GH, IGF-1 and IGFBP-3

\begin{tabular}{llccr}
\hline & & $\begin{array}{c}\text { April, 1998 } \\
\text { On admission }\end{array}$ & $\begin{array}{c}\text { February, 2002 } \\
\text { Before operation }\end{array}$ & $\begin{array}{c}\text { April, 2002 } \\
\text { After operation }\end{array}$ \\
\hline GH & $\mathrm{ng} / \mathrm{ml}$ & 6.9 & 2.2 & $0.1>$ \\
IGF-1 & $\mathrm{ng} / \mathrm{ml}(121-436)^{*}$ & 316 & 462 & 109 \\
IGFBP-3 & $\mu \mathrm{g} / \mathrm{ml}$ & $2.64(2.44-5.2)^{*}$ & $2.89(1.99-3.20)^{*}$ & 1.73 \\
Urinary GH/Cre & $\mathrm{pg} / \mathrm{mg} \mathrm{Cre}(2.5-11)^{*}$ & 24.1 & 26.6 & $15.7>$ \\
Blood glucose & $\mathrm{mg} / \mathrm{dl}$ & $\mathrm{NM}$ & 187 & 183 \\
\hline
\end{tabular}

Abbreviations: NM, not measured.

* Numbers in parentheses indicate the normal range. 

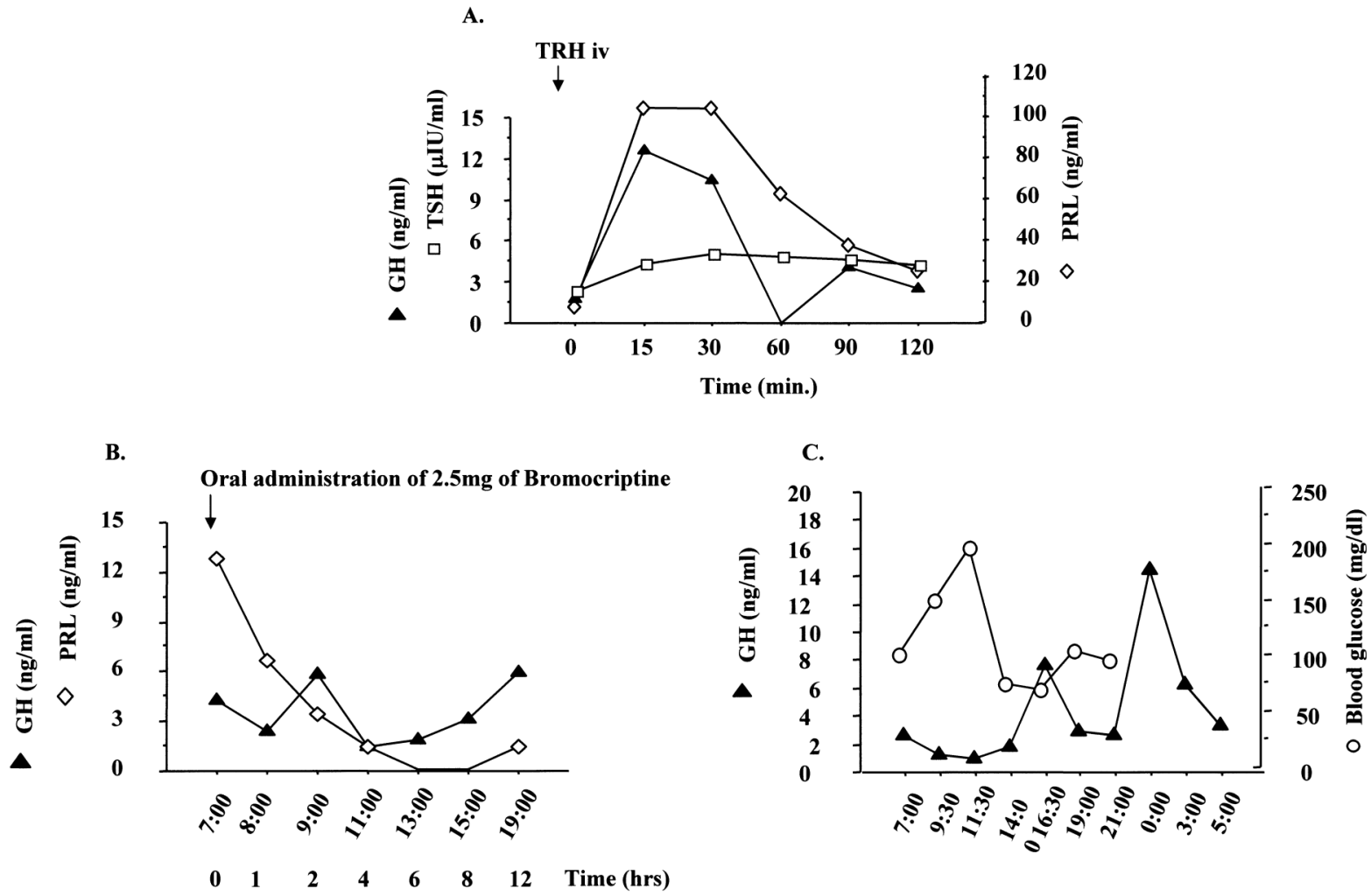

Fig. 1. Endocrinological stimulation tests on admission in April, 1998.

(A) TRH stimulation test. Responses of GH, PRL and TSH to TRH were discrepantly hyperactive (as blood GH level increased to $12.6 \mathrm{ng} / \mathrm{ml}$ ), hyperactive and hypoactive, respectively.

(B) Bromocriptine suppression test. Blood levels of GH at 4 hours and PRL at 6-8 hours after an oral administration of $2.5 \mathrm{mg}$ of bromocriptine were suppressed.

(C) Circadian rhythm of blood GH levels. Although her fasting blood GH level in the morning was slightly high, the circadian rhythm of blood GH levels was normally maintained.

A.

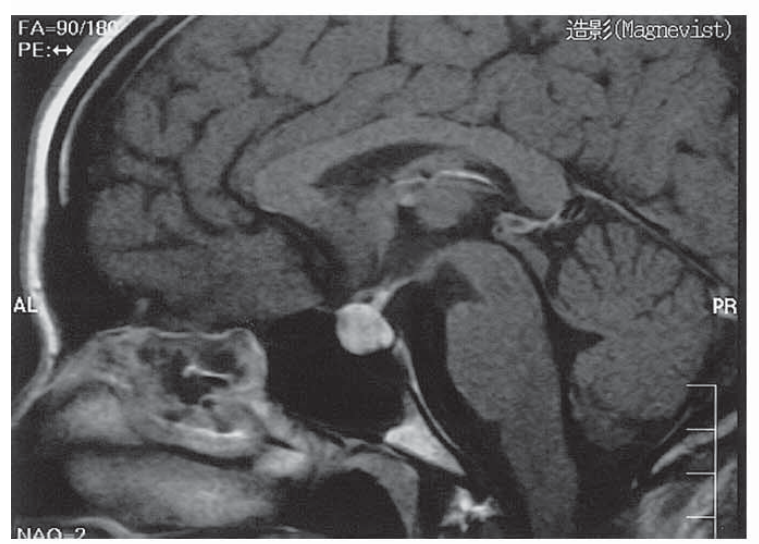

B.

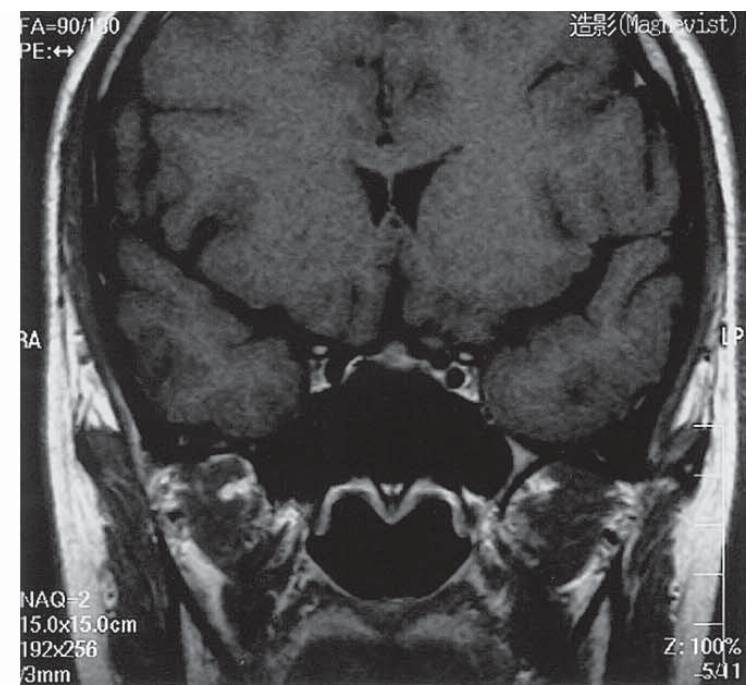

Fig. 2. Pituitary MRIs on May 1, 1998 .

Enhanced MRIs show pituitary swelling, but no nodule in the pituitary. 


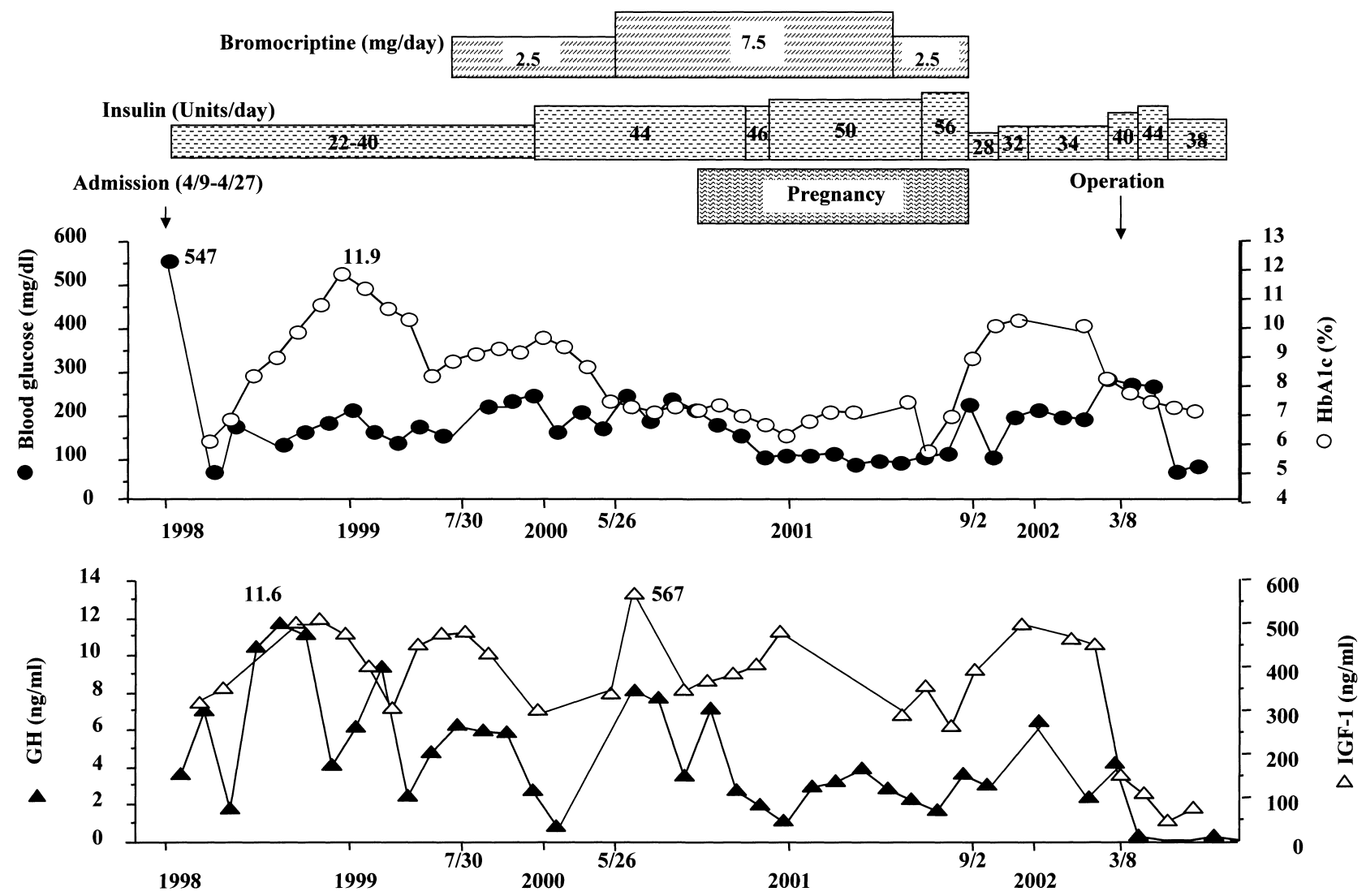

Fig. 3. Clinical course.

A woman was diagnosed as having type 1 diabetes mellitus and acromegaly in 1998. As MRIs showed no nodule in the pituitary, we observed her as having acromegaly without necessitating surgery, and prescribed a medical treatment of insulin therapy for the diabetes. We started a treatment of oral administration of bromocriptine for the acromegaly beginning April 28 , 2000, because high blood levels of GH were suspected of causing the diabetes to be poorly controlled. While taking the treatments of bromocriptine for acromegaly and insulin for diabetes during a pregnancy from October, 2000 to September, 2001, she delivered a normal infant. After delivery, her pituitary tumor became enlarged, and a transsphenoidal surgery for the tumor was performed on March 8, 2002. After the surgery, blood levels of GH and IGF-1 lowered and diabetic control improved.

$50-60 \mathrm{mg} / \mathrm{dl}$ ) and jaundice (total bilirubin $14.9 \mathrm{mg} / \mathrm{dl}$ ), but showed no deformities. After delivery, the oral administration of bromocriptine was stopped because she hoped to breastfeed. Thereafter, blood levels of GH and IGF-1 became elevated and her diabetic control deteriorated (Fig. 3). In February, 2002, although blood IGFBP-3 level was within the normal range, her blood levels of GH $(2.2 \mathrm{ng} / \mathrm{ml})$ and IGF-1 $(462 \mathrm{ng} / \mathrm{ml})$ and urinary $\mathrm{GH} / \mathrm{Cr}$ excretion $(26.6 \mathrm{pg} / \mathrm{mgCr})$ were high (Table 3). An enhanced MRI on February 2, 2002, showed one low intensity lesion of about $8 \mathrm{~mm}$ diameters in the anterior lobe of the pituitary (Fig. 4A, B). As the pituitary tumor gradually became larger, she underwent a transsphenoidal surgery for one pituitary tumor on March 8, 2002.

From the pathological point of view, the pituitary tumor was composed of acidophilic cells (Fig. 5). Immunohistochemical staining of GH and PRL was done using a $\times 100$ dilution of anti-GH serum (Novocastra, Newcastle, UK) and a $\times 100$ dilution of anti-PRL serum (Novocastra, Newcastle, UK), respectively. The tumor cells showed strong and diffuse cytoplasmic immunoreactivity for GH, but not for PRL (data not shown). This pituitary tumor was diagnosed as a GH-producing and closely granulated somatotroph adenoma.

After the surgical resection of the pituitary tumor, blood levels of GH, IGF-1 and IGFBP-3 lowered and diabetic control improved (Table 3 ). 

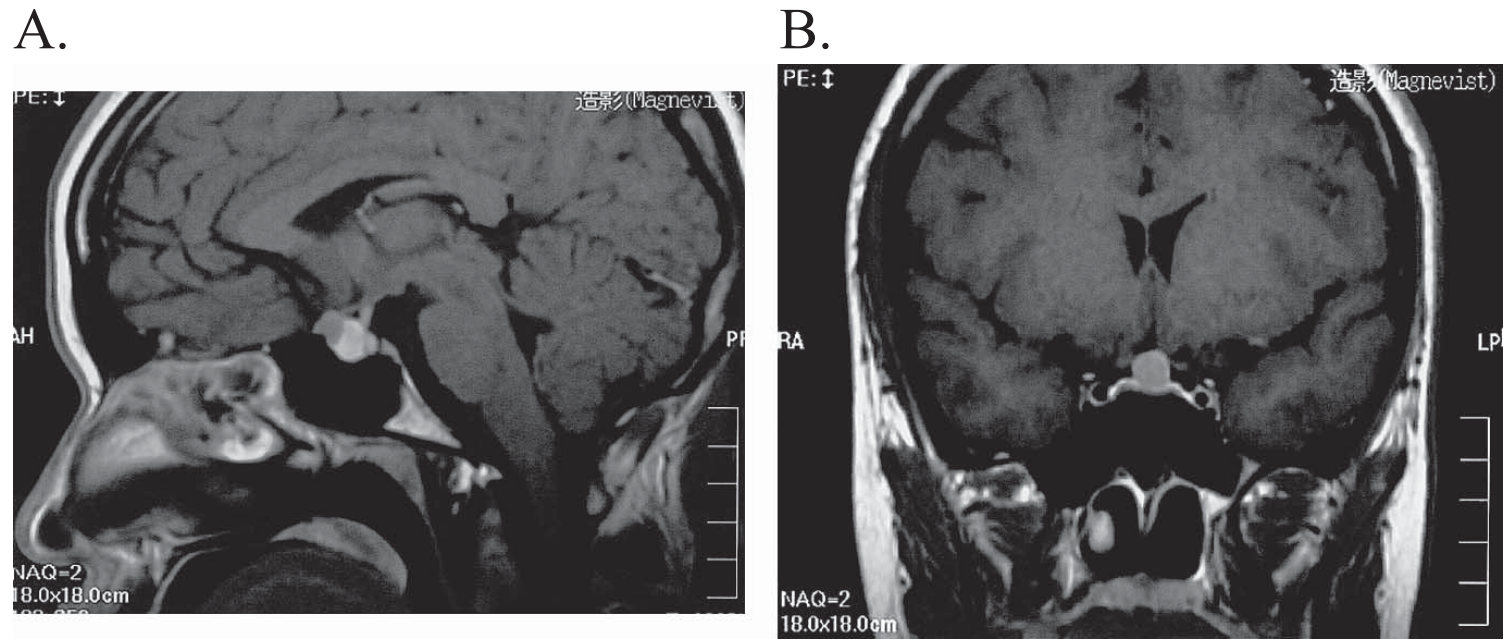

Fig. 4. Pituitary MRIs on February 22, 2002. Enhanced MRIs show one low intensity lesion of about $8 \mathrm{~mm}$ diameters in the anterior lobe of the pituitary.

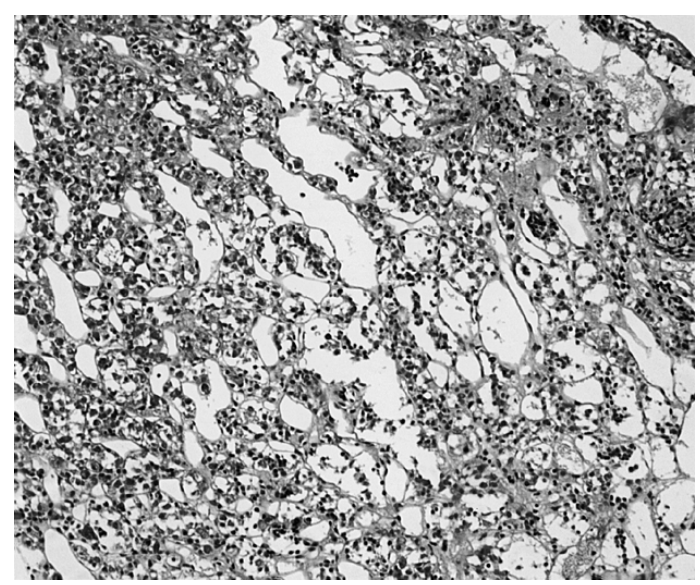

Fig. 5. Pathology of the pituitary tumor.

The pituitary tumor was composed of acidophilic cells. The tumor cells showed strong and diffuse cytoplasmic immunoreactivity for GH, but not for PRL. This pituitary tumor was diagnosed as a GH-producing and closely granulated somatotroph adenoma.

\section{Discussion}

We report here a woman who was diagnosed as having acromegaly when suffering from a sudden onset of type 1 diabetes. As insulin induces the expression of $\mathrm{GH}$ receptors on hepatocytes, which are the major sites of IGF-1 production, poorly controlled diabetes with a lack of insulin action leads to a state of hepatic GH resistance. Consequently, $\beta$-cell dysfunction causes blood GH levels to elevate and blood IGF-1 levels to lower or normalize [9]. Thus, high blood GH levels do not always mean acromegaly. The diagnostic evaluation of acromegaly is undertaken by noting clinical symptoms, high blood levels of GH and IGF-1, and the existence of a pituitary tumor seen in MRIs [2]. The measurements of serum IGF-1 or IGFBP-3 have been reported as being more valuable for diagnosing acromegaly in type 1 diabetes than a single measurement of $\mathrm{GH}[7,8]$. In the present case, although blood IGFBP-3 levels were always within the normal range, blood levels of GH and IGF-1 were frequently high and a mass was observed on pituitary MRI. Based on the above findings we diagnosed our patient as having acromegaly. Thus, we considered that the measurements of serum GH and IGF-1 and the pituitary MRIs may be valuable for the diagnosis of acromegaly in type 1 diabetes.

The treatments of acromegaly should adequately be selected among medical therapy, radiation, or surgery [11]. As MRIs on first admission showed no mass in her pituitary, we initially chose medication. Although bromocriptine used for acromegaly lowered blood GH levels, her pituitary tumor enlarged after pregnancy. This suggests that pregnancy may aggravate pituitary tumor growth [12], and in a small number of cases, acromegaly was reported to be exacerbated during pregnancy [12-15]. As her pituitary tumor clearly became larger in the course of observation, we conducted transsphenoidal surgery on March 8, 2002. We pathologically diagnosed the specimen as a GH-producing pituitary adenoma because it was immunohistochemically stained with an anti-GH serum. 
Her clinical features, such as sudden onset of diabetes, high titers of anti-GAD antibodies, and low levels of urinary CPR excretion, were compatible with type 1 diabetes. In addition, the patient was shown to possess an HLA allele susceptible to type 1 diabetes, as DR3, DR4, HLA-DNA typing DQB1*0301, and DQB1*0201 [10]. Therefore, we diagnosed her as having type 1 diabetes and started her on an intensive insulin therapy for the condition. Late pregnancies have been known to contribute to insulin resistance [20], of which there are various factors causing this, such as free fatty acid (FFA) and tumor necrosis factor- $\alpha($ TNF- $\alpha)$ [16-19]. Acromegalic patients during pregnancy are therefore at a greater risk for hyperglycemia $[2,3,20]$. Diabetic control during pregnancy in the present case was improved by the combined treatment of bromocriptine for acromegaly and insulin for diabetes.
In several reports, bromocriptine has been reported to be useful throughout pregnancy without any teratogenic effects because it does not affect the expected pattern of placental hormone secretion $[21,22]$. In the present case, while the patient received the treatments of bromocriptine for acromegaly and insulin for type 1 diabetes during her pregnancy, she was eventually able to have a successful pregnancy and deliver a normal full-term infant.

Thus, we reported a rare case of type 1 diabetes mellitus associated with acromegaly, who was diagnosed by both endocrinological stimulation tests and pituitary MRIs after being observed for about 4 years. We concluded that to rule out acromegaly in patients with poorly controlled diabetes, 1) measurements of serum GH and IGF-1 should be performed, and 2) pituitary MRIs should be performed if blood levels of GH or IGF-1 are high.

\section{References}

1. Berelowitz M, Kourides LA (2000) Diabetes mellitus secondary to other endocrine disorders. In: LeRoith D, Taylor SI, Olefsky JM (eds), Diabetes Mellitus. A Functional and Clinical text, $2^{\text {nd }}$ ed., New York, Lippincott-Raven, 588-595.

2. Melmed S, Kleinberg D (2002) Anterior pituitary. In: Larsen PR, Kronenberg HM, Melmed S, Polonsky KS (eds), Williams Textbook of Endocrinology, $10^{\text {th }}$ ed., WB Saunders, Philadelphia, 177-279.

3. Davidson MB (1987) Effect of growth hormone on carbohydrate and lipid metabolism. Endocr Rev 8: 115131.

4. Press M, Tamborlane WV, Sherwin RS (1984) Importance of raised growth hormone levels in mediating the metabolic derangements of diabetes. $N$ Engl $J$ Med 310: 810-815.

5. Vigneri R, Squatrito $S$, Pezzino V, Filetti $S$, Branca $S$, Polosa P (1976) Growth hormone levels in diabetes correlation with clinical control of the diabetes. Diabetes 25: 167-172.

6. Wurzburger MI, Prelevic GM, Sonksen PH, Peric LA, Till S, Morris RW (1990) The effect of improved blood glucose on growth hormone and cortisol secretion in insulin dependent diabetes mellitus. Clin Endocrinol (Oxf) 32: 787-797.

7. Herlihy OM, Perros P (2000) Elevated serum growth hormone in a patient with Type 1 diabetes: a diagnostic dilemma. Diabetes Metab Res and Rev 16: 211-216.

8. Hofmann EA, Polonsky KS, Weiss RE (2002) Diagnosis of acromegaly in a patient with type 1 diabetes mellitus. Endocr Pract 8: 113-118.
9. Wurzburger MI, Sonksen PH (1996) Natural course of growth hormone hypersecretion in insulin-dependent diabetes mellitus. Med Hypotheses 46: 145-149.

10. She JX (1996) Susceptibility to type 1 diabetes: HLADQ and DR revised. Immunol Today 17: 323-329.

11. Melmed S, Vance ML, Barkan AL, Bengtsson BA, Kleinberg D, Klibanski A, Trainer PJ (2002) Current status and future opportunities for controlling acromegaly. Pituitary 5: 185-196.

12. Herman-Bonert V, Seliverstov M, Melmed S (1998) Pregnancy in acromegaly: successful therapeutic outcome. J Clin Endocrinol Metab 83: 727-731.

13. Molitch ME (2003) Pituitary tumors and pregnancy. Growth Horm IGF Res 13 (Suppl): S38-S44. 1674S$1683 \mathrm{~S}$.

14. Kupersmith MJ, Roseberg C, Kleinberg D (1994) Visual loss in pregnant women with pituitary adenomas. Ann Intern Med 121: 473-477.

15. Okada Y, Morimoto I, Ejima K, Yoshida K, Kashimura M, Fujihira T, Eto S (1997) A case of acute acromegalic woman with a marked increase in serum insulin-like growth factor-1 levels after delivery. Endocr $J$ 44: $117-120$.

16. Iwai H, Ohno Y, Aoki N (2003) The effect of leptin, tumor necrosis factor- $\alpha$ (TNF- $\alpha$ ), and nitric oxide (NO) production on insulin resistance in Otsuka Long-Evans Fatty rats. Endocr J 50: 673-680.

17. Borden G (1997) Role of fatty acids in the pathogenesis of insulin resistance and NIDDM. Diabetes 46: 310.

18. Peraldi P, Spiegelman B (1998) TNF- $\alpha$ and insulin 
resistance: summary and future prospects. Mol Cell Biochem 182: 169-175.

19. Hotamisligil GS, Shargill NS, Spiegelman BM (1993) Adipose expression of tumor necrosis factor- $\alpha$ : direct role in obesity-linked insulin resistance. Science 259: 87-91.

20. Buchanan TA (2000) Intermediary metabolism during pregnancy. Implications for diabetes mellitus. In: LeRoith D, Taylor SI, Olefsky JM (eds), Diabetes Mellitus. A Functional and Clinical Text, $2^{\text {nd }}$ ed., New
York, Lippincott-Raven, 844-852.

21. Bigazzi M, Ronga R, Lancranjan I, Ferraro S, Branconi F, Buzzoni P, Martorana G, Scarselli GF, Del Pozo E (1979) A pregnancy in an acromegalic woman during bromocriptine treatment: effects on growth hormone and prolactin in the maternal, fetal and amniotic compartments. J Clin Endocrinol Metab 48: 9-12.

22. Neal JM (2000) Successful pregnancy in a woman with acromegaly treated with octreotide. Endocr Pract 6: 148-150. 